\title{
Nanoparticle-based drilling fluids as promising solutions to enhance drilling performance in Egyptian oil and gas fields
}

\author{
Ahmed Mady ${ }^{*}$, Omar Mahmoud ${ }^{2}$ and Abdel Sattar Dahab ${ }^{3}$ \\ 1, 2 Department of Petroleum Engineering, Future University in Egypt (FUE) \\ ${ }^{3}$ Department of Petroleum Engineering, Cairo University \\ * Corresponding author: ahmed.mady@fue.edu.eg
}

\begin{abstract}
Over the years, the discovery of petroleum in various regions of the world has led to the development of different techniques and equipment to enhance and optimize the drilling and production operations in this vital industry. Egypt is both one of the major oil-producing non-OPEC countries and one of the oldest energy producers in the Middle East. Recently, the Egyptian government have signed several agreements for the exploration of oil and gas in several provinces/regions including; the Mediterranean, the Western desert, the Nile Delta, and the Gulf of Suez. Petroleum companies have given great attention to Egypt's new discoveries such as Zohr Gas Field, and Nour exploration prospect. Successful drilling operations to reach the oil and gas targets depends strongly on the effectiveness of the drilling fluids. Drilling fluids can be considered as the heart of the drilling process. They are used to fulfil several functions, such as controlling pressure, carrying cuttings and cooling bit and drill strings, stabilizing wellbore as well as controlling fluid losses.
\end{abstract}

Drilling fluid technology is one of the most targeted and developed technologies worldwide. Several studies have examined the use of various types of nanoparticles (NPs) as additives to enhance the properties and improve the performance of the drilling fluid to mitigate the drilling problems. NPs can be defined as a simplest structure with a size in the range of nanometers. The effectiveness of NPs can be accredited to their small sizes and thus, high surface-area-to-volume ratio. NPs were also showed promising enhancements on the rheological and filtration characteristics of the drilling fluid (mud). Additionally, swelling and collapse of shale formations is expected under drilling with water-based mud, which might result in complicating the drilling operation. Adding NPs to the drilling mud was found to minimize the shale permeability and thus, promote the wellbore stability.

This research paper discusses the latest applications and presents the most valuable findings concerning the efficient use of NPs in the drilling fluid industry. Based on that, different recommendations are stated. This might help researchers to better understand NPs' functionality in this area of application and promote using NPs-based drilling muds as cost-effective and environmental-friendly fluids to drill the Egyptian oil and gas wells.

Keywords: Egyptian drilling-challenges; Drilling fluids; Nanoparticle applications; Rheological and filter cake characteristics; Wellbore stability, Reactive shales.

\section{1- Introduction}

The petroleum industry is facing new and difficult technical challenges while reacting with the growing global energy demand. Critical issues related to remote locations, harsh conditions 
(high pressure and high temperature formations), unconventional oil reservoirs (heavy oils, tight gas, tar sands, etc.). Conventional methods of exploration and production might not be able to keep up with this growing demand. Technological innovations are needed to successfully meet the energy challenge.

Oil and gas are important to Arab economies. Egypt is both one of the major oil-producing non-OPEC countries and one of the oldest energy producers in the Middle East. Currently, more than 50 international oil companies are working in Egypt. Zohr is the largest gas discovery ever made in Egypt and in the Mediterranean and could become one of the world's largest natural-gas finds.

Depletion of many conventional oil and gas reserves and increasing demand for energy has increased the importance of drilling shale formations. While shale has been traditionally considered as hydrocarbon source and/or seal rocks, shale plays are now recognized as major hydrocarbon reservoir rocks. The unconventional hydrocarbon resources, including gas and oil shale, have blossomed in the recent years. Worldwide, likely recoverable shale gas reserves exceed 250 Tcf by some estimates, with over 10 times that speculated to be in place. In North America, shale gas has been one of the most rapidly expanding trends in onshore domestic natural gas exploration and exploitation [27].

Over the last decades, the oil industry is giving nanotechnology growing interest and expectations. Nanotechnology has opened the door to the development of a new generation of Fluids mixed with nanosized particles for drilling, production, and stimulation-related applications. The characteristics of nanoparticles (NPs) that make them particularly attractive to the oil and gas exploration and production are their small sizes and thus, high surface-areato-volume ratio. The nanotechnology might become a key factor in all the branches of the petroleum industry: from asset exploration to well drilling and completion, and from production to reservoir monitoring and management. Nano-materials can be used to change reservoir properties such as wettability and improve mobility ratio. Its capability as a less expensive, more efficient, and environmentally friendly material might giving it a more promising role in the coming developments. However, many of the applications are still only in laboratory and research phases.

NPs-drilling-fluids are applicable in the case of unconventional and/or water-reactive shale where the effect of traditional shale inhibitors is of little or no use. It is common to drill through reactive shale in the process of reaching unconventional shale plays. In this instance, a combination of traditional chemical shale inhibitors and physical wellbore stabilizers is necessary in the drilling fluid system. This approach would be able to virtually overcome any shale issue encountered by proactively plugging nanopores while inhibiting the water absorption in shale formations.

NPs-based drilling fluids can also offer good lubricity and therefore are suitable for applications of drilling the lateral section in shales. Tests were conducted to measure the extent of invasion of water into shales when they are exposed to NPs-based drilling fluids [27], [29]. Fluid invasion into shales was reported to be reduced by 10 to 100 times, which indicating the minimization of wellbore instability problems. Fig. 1 presents the scanning electron 
microscopy (SEM) of the different shapes of NPs-plugging the pore throat of the shales. Drilling long lateral sections in shales and tight gas reservoirs is often the largest capital cost associated with the development of these resources. NPs-based muds have the potential to significantly cut these drilling and disposal costs and offer significant environmental benefits.
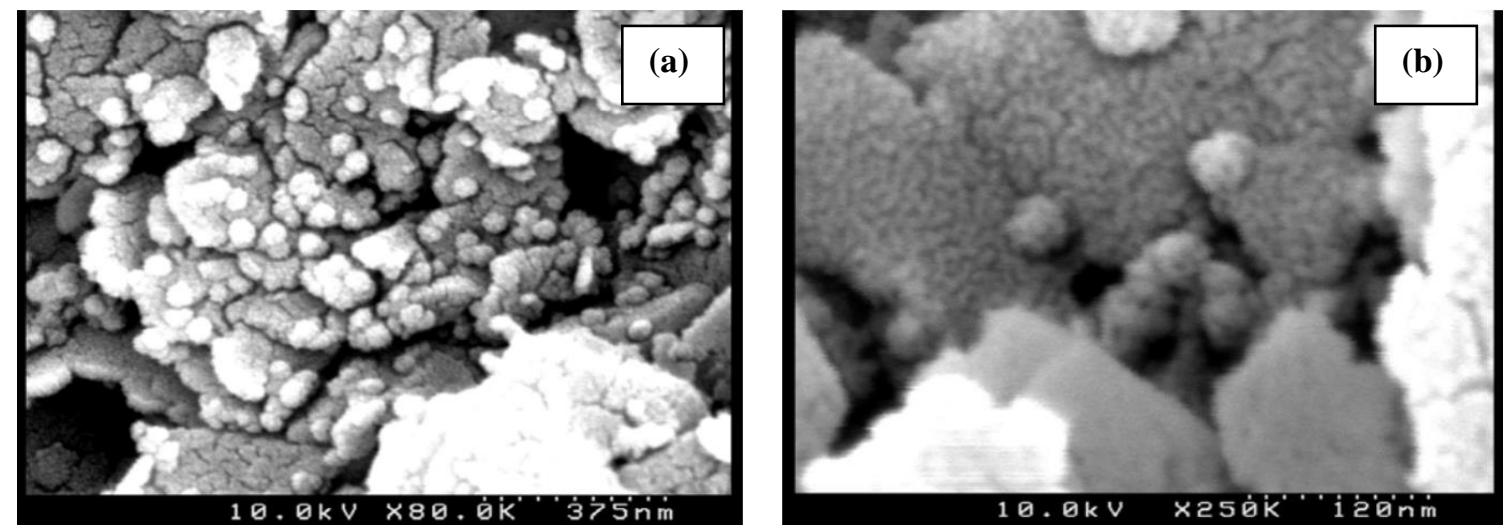

Fig. 1 SEM images of: (a) NPs plugging different pore throats, (b) aggregated particles plugging a pore throat (modified after [27]).

Drilling operations of both conventional and unconventional oil and gas accumulations are becoming more challenging in deep-water operations. Due to the narrow mud weight window in offshore wells, a proper wellbore stability analysis is required for a cost-effective execution. Wellbore strengthening by using the NPs is an approach used to increase the fracture pressure of the rock, widen the mud window, and consequently enhance the well integrity and mitigate mud losses [6].

Different types of NPs have been investigated as rheological property controllers, fluid loss reducers, and shale stabilizers in many drilling fluid applications [17]. In the following sections, a brief review of nanotechnology applications in the drilling fluids industry has been presented. Additionally, the results out of the characterization of two Egyptian black-shale samples have been reported. The first sample is from the Duwi formation shale deposits at Safaga-Quseir area, Egypt. The second one is from the Dakhla formation, which recognized throughout the stable shelf region of Egypt, with the type locality at the Dakhla Oasis in the central Western Desert. Both samples are characterized for the objective of a future investigation of the effect of using NPs-based drilling fluids on their swelling properties and stability, which will be discussed in future publications.

\section{2- Background}

\section{NPs Applications as Fluid Loss Controllers and Rheological Property Modifiers:}

In 2011, the formulation of the three nano-based drilling fluids was investigated by [3]. The authors noticed difficult NPs stabilization in the drilling fluid without using chemical additives. To reach a stabilize and homogeneous nanofluid, highly effective surfactants or polymers with high neutralizing capabilities were used. The investigation showed also that the addition of NPs 
yielded a decrease in spurt and fluid loss volumes and produced a thin filter cake, which can reduce the differential pipe sticking problems. Later in the same year, the rheological properties of $5 \mathrm{wt} . \%$ bentonite fluids containing ferric oxide $\left(\mathrm{Fe}_{2} \mathrm{O}_{3}\right)$ NPs of 3 and $30 \mathrm{~nm}$ at different temperatures $\left(20-200^{\circ} \mathrm{C}\right)$ and pressures (1-100 atm) were studied [13]. The results indicated that yield stress and viscosity increased by increasing the concentration of $\mathrm{Fe}_{2} \mathrm{O}_{3} \mathrm{NPs}$. Furthermore, the API filtration tests showed higher reduction in the fluid loss by the addition of $0.5 \mathrm{wt} . \%$ of the $30 \mathrm{~nm}-\mathrm{Fe}_{2} \mathrm{O}_{3}$ NPs. Higher concentration (5 wt.\%) led to reduce the fluid loss capacity.

The laboratory results of [12] showed that the $\mathrm{SiO}_{2}$ NPs with sizes of 40-130 nm did not affect the rheological properties of drilling fluids but had a significant effect on the reduction of mud cake thickness. In another research, a new type of clay NPs had been produced and examined by [1]. It is mainly composed of montmorillonite and has low viscosity and high gel strength with bentonite at high pressure/high temperature (HP/HT) conditions as the authors stated. This type of clay-NPs can give good rheological stability and suitable characteristics of maintaining low viscosity without affecting the density.

Using graphene oxide $(G O)$ NPs as fluid loss controller was investigated by [14]. It was examined in an aqueous dispersion and by combination of large flake $G O$ and powdered GO in a 3:1 ratio. This ratio revealed an enhancement in the filtration characteristics in addition to good stability at high temperature. [24] and [7] examined the effect of Carboxy Methyl Cellulose $(C M C)$ and Poly Anionic Cellulose (PAC) polymers as NPs additives. The results revealed improvement in both the mud cake thickness and fluid loss rather than using conventional polymers of the same type but regular sizes.

[13] examined the effectiveness of using two types of NP intercalated clay hybrids, ironoxide clay hybrid $(\mathrm{ICH})$ and aluminosilicate clay hybrid $(\mathrm{ASCH})$ on the properties of bentonite suspensions. The results showed a reduction in the fluid loss of up to $37 \%$ and $47 \%$ in both low pressure/low temperature (LP/LT) and HP/HT fluid loss when using ICH and ASCH with bentonite fluids. Furthermore, it was found that adding $0.5 \mathrm{wt} \%$ of pure $\mathrm{Fe}_{2} \mathrm{O}_{3}$ NPs (3 and $30 \mathrm{~nm}$ ) into bentonite suspensions increased the API fluid loss by $14 \%$ compared to the base; however, it decreased the filtration volume at HP/HT by $28 \%$ compared to the base fluid. Moreover, the authors concluded that the reduction in both LP/LT and HP/HT filtrate volume when using clay hybrids ( $I C H$ and $A S C H$ ) was because of the reconstruction of clay platelet in suspension due to the changes in surface charge. Fig. 2 shows the SEM images with the corresponding illustrations of bentonite clay platelet interaction, which were used to demonstrate the aforementioned conclusions. 


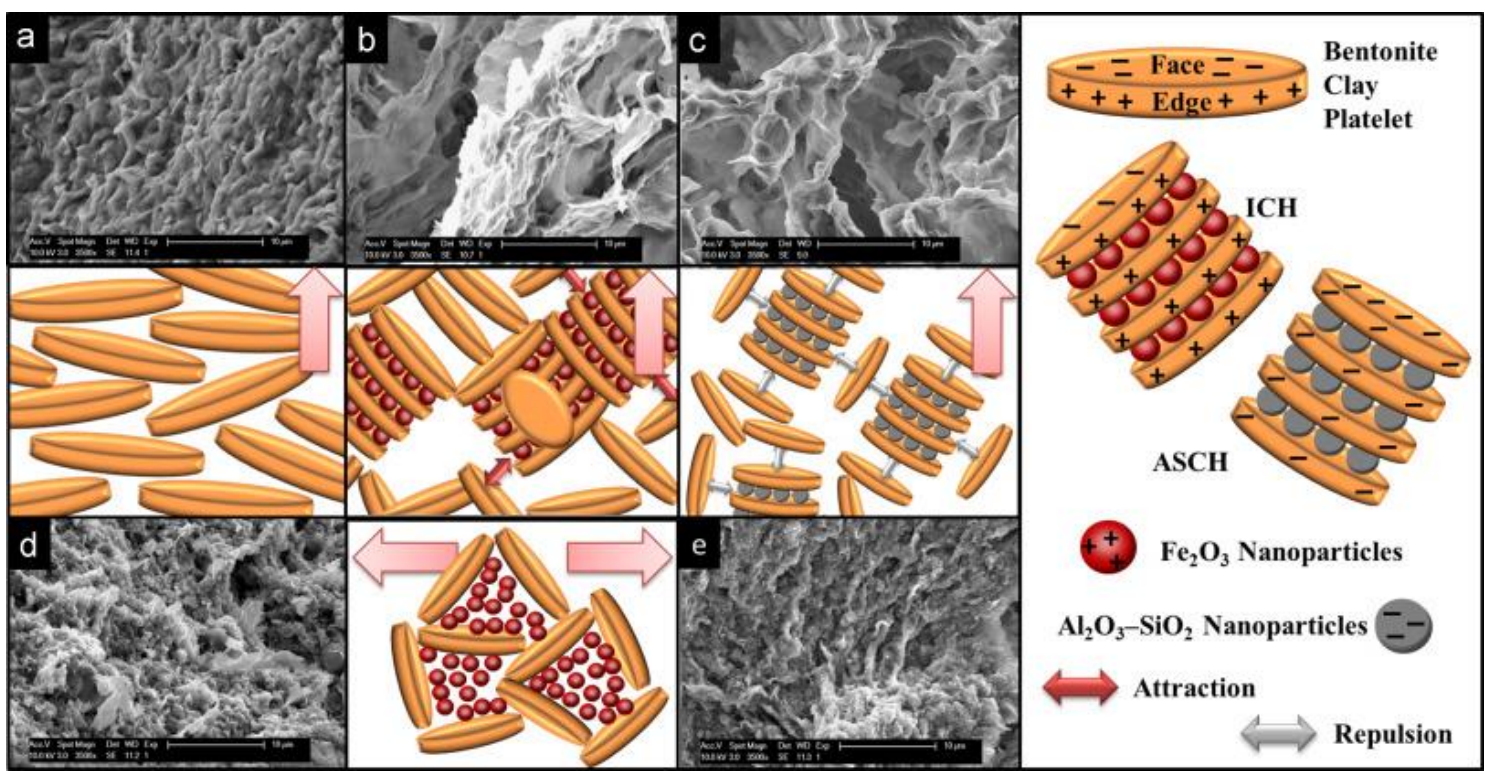

Fig. 2 SEM images of the filter cakes after LP/LT filter press experiments for different samples with the corresponding illustrations of bentonite clay platelet interaction (modified after [13]).

Cellulose Nanoparticles (CNPs) and Microfibrillated Cellulose (MFC) were also tested as drilling fluid property modifiers [15]. A great enhancement in rheological properties was observed when using both of them. CNPs were found to reduce fluid loss capacity and filter cake thickness. However, using $M F C$ yielded an increase in the filter cake thickness and had a little effect on fluid loss. When using a combination of Multi-Walled Carbon Nanotube (MWCNT) and nanosilica, improvements of plastic viscosity (PV) and yield point (YP) of the drilling fluid were found in addition to a fluid loss reduction [11]. The effect of adding nanofluids of copper oxide and zinc oxide NPs on the thermal and filtration properties of mud was also examined and compared with a microfluid enhanced drilling mud (MWBM). Improvement of thermal and filtration properties were recorded compared to MWBM. Furthermore, thicker filter cakes were produced when using MWBM compared to the case of using NPs.

The work in [25] and [26] examined the use anionic NPs (nanosilica, nanotitanium and nanoaluminium). They revealed the ability of nanosilica in a concentration of $0.1 \mathrm{wt} . \%$ or less to improve the rheological properties and hydraulics and reduce the filtration volume and mud cake thickness. The same results were reported when using nanotitanium and nanoaluminium by 0.3 wt. $\%$ or less, but no filtration reduction was observed with nanoaluminium. Additionally, adding 0.1wt.\% of nanosilica reduced the Equivalent Circulating Density (ECD) from $9.7 \mathrm{lb} /$ gal to $9.2 \mathrm{lb} / \mathrm{gal}$. A low ECD will help in reducing the formation fracture and loss circulation. The authors reported also a negative impact of the NPs when added above $0.7 \%$ by weight.

The work in [19] and [20] showed that adding $\mathrm{Fe}_{2} \mathrm{O}_{3}$ NPs in a concentration of 0.3-0.5 wt.\% yielded better rheological properties and filter cake characteristics of a bentonite-based drilling fluid. On the other hand, the addition of silica NPs decreased the YP but showed better rheological stability. They also reported that the surface charge of NPs and their stability in suspension playing a key role in the NPs' dynamics with the other drilling fluid additives as revealed from zeta potential measurements. Additionally, adding $\mathrm{Fe}_{2} \mathrm{O}_{3} \mathrm{NPs}$ produced a good- 
quality filter cake as the NPs embedded randomly in the clay platelet structure at the elevated temperatures as showed by computed-tomography CT) scan and scanning electron microscopy (SEM).

The work in [18] evaluated the effect of using different types of NPs with a bentonite-based drilling fluid. Different types of oxide NPs $\left(\mathrm{Fe}_{2} \mathrm{O}_{3}, \mathrm{Fe}_{3} \mathrm{O}_{4}, \mathrm{ZnO}\right.$, and $\left.\mathrm{SiO}_{2}\right)$ with different surface charge and stability in suspensions were used to investigate the effect of NPs-type and -concentration. CT scan technique was used to assess the formation damage based on the change of porosity of the filter-medium as a result of the invasion of filtrates and small particles during the filtration process. Fig. 3 shows the CT scan images of the filter cake of the sample that have $0.5 \mathrm{wt} . \%$ of $\mathrm{Fe}_{3} \mathrm{O}_{4}$ NPs generated under static conditions at a differential pressure of 300 psi and $250^{\circ} \mathrm{F}$.
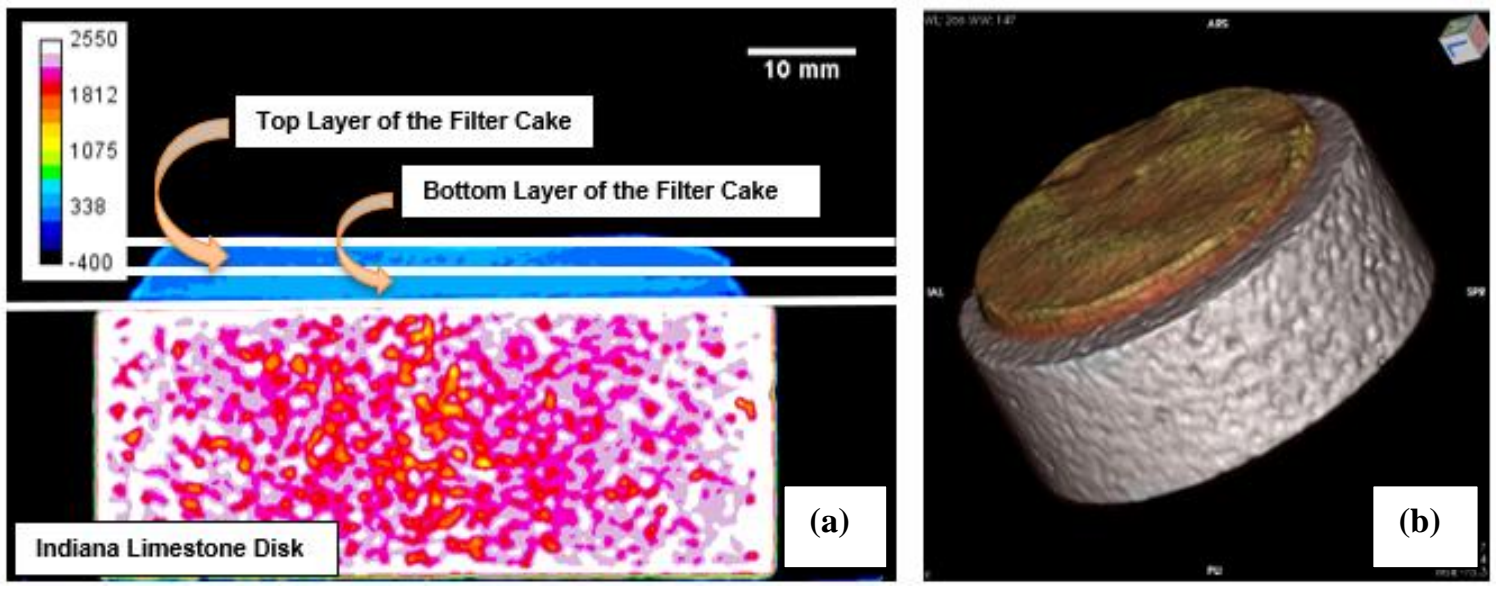

Fig. 3 CT scan images of the filter cake of the sample that have $0.5 \mathrm{wt} \%$ of $\mathrm{Fe}_{3} \mathrm{O}_{4} \mathrm{NPs}$ generated under static conditions at a differential pressure of 300 psi and $250^{\circ} \mathrm{F}$ : (a) $2 \mathrm{D}$ image with $\mathrm{CTN}$-calibration scale, and (b) 3D cross-section. The calibration legend is in Hounsfield units (HU) (modified after [18]).

Different types of metal oxide NPs, including $\mathrm{Al}_{2} \mathrm{O}_{3}, \mathrm{CuO}$, and $\mathrm{MgO}$, were examined as drilling fluid additives at different concentrations and conditions [2]. The addition of NPs increased the gel strength with the best performance when adding higher concentration of $\mathrm{CuO}$. However, increasing the concentration of $\mathrm{Al}_{2} \mathrm{O}_{3}$ and $\mathrm{MgO}$ decreased the gelation. Adding NPs were also reported to improve YP and PV at the studied conditions. [4] checked both $\mathrm{SiO}_{2}$ and Graphene-NPs $(G N P s)$. A significant improvement in the filtration properties were observed when a mixture of $0.5 \mathrm{wt} . \%$ of $\mathrm{SiO}_{2}$ and $0.25 \mathrm{wt} . \%$ of $\mathrm{GNPs}$ with a neglect effect on the spurt loss, PV, and YP. However, the GNPs samples yielded higher gel strength compared to the fluids containing $\mathrm{SiO}_{2}$ NPs.

A good representation of the drilling fluid compositions, the NPs' types and concentrations, the experimental conditions, and the results obtained from various studies in the literature in the field of improving the properties of bentonite-based drilling fluids are shown in Table $\mathbf{1}$. 
Table 1: Comparative study between various bentonite-based drilling fluids modified using different types of NPs (modified after [20]).

\begin{tabular}{|c|c|c|c|c|c|c|c|}
\hline \multirow{3}{*}{ Study } & \multirow{3}{*}{$\begin{array}{l}\text { Drilling Fluid } \\
\text { Composition }\end{array}$} & \multirow{3}{*}{$\begin{array}{l}\text { Drilling } \\
\text { Fluid } \\
\text { Density, } \\
\text { ppg }\end{array}$} & \multicolumn{2}{|c|}{ Conditions } & \multirow{3}{*}{ Type of NPs } & \multirow{3}{*}{$\begin{array}{c}\text { Concentration } \\
\text { of NPs }\end{array}$} & \multirow{3}{*}{$\begin{array}{c}30 \text { min- } \\
\text { Cumulative } \\
\text { Filtrate } \\
\text { Volume, } \\
\text { mL }\end{array}$} \\
\hline & & & $\begin{array}{l}\text { Differential } \\
\text { Pressure, }\end{array}$ & Temperature, & & & \\
\hline & & & Psi & ${ }^{\circ} \mathbf{F}$ & & & \\
\hline \multirow{2}{*}{$\begin{array}{l}\text { Song et } \\
\text { al. }(2016)\end{array}$} & \multirow{2}{*}{$\begin{array}{c}350 \mathrm{ml} \text { water, } \\
\text { Bentonite, NaOH, } \\
\text { Lignite, PAC, Calcium } \\
\text { Montmorillonite Clay, } \\
\text { and NPs }\end{array}$} & \multirow{2}{*}{ - } & \multirow{2}{*}{1,000} & \multirow{2}{*}{200} & $\begin{array}{c}\text { Cellulose } \\
\text { Nanocrystals }\end{array}$ & $3.5 \mathrm{~g}$ & 28 \\
\hline & & & & & $\begin{array}{l}\text { Cellulose } \\
\text { Nanofibers }\end{array}$ & $3.5 \mathrm{~g}$ & 18 \\
\hline \multirow{3}{*}{$\begin{array}{l}\text { Parizad } \\
\text { and } \\
\text { Shahbazi } \\
(2016)\end{array}$} & $\begin{array}{c}\text { Xanthan Gum (XG), } \\
\text { KOH, }\end{array}$ & \multirow{3}{*}{ - } & \multirow{3}{*}{400} & \multirow{3}{*}{200} & \multirow{3}{*}{$\mathrm{SnO}_{2}$} & $1 \mathrm{~g} / 1$ & 11.9 \\
\hline & Carboxymethyle & & & & & & \\
\hline & $\begin{array}{l}\text { Cellulose (CMC), } \\
\text { Bentonite, and NPS }\end{array}$ & & & & & $5 \mathrm{~g} / 1$ & 13.1 \\
\hline \multirow{4}{*}{$\begin{array}{l}\text { Smith et } \\
\text { al. (2018) }\end{array}$} & \multirow{4}{*}{$\begin{array}{c}350 \mathrm{ml} \text { Water, } \\
22.5 \mathrm{~g} \text { Bentonite, } \\
20.3 \mathrm{~g} \text { Barite, } \\
\text { PAC, XG, } \\
\text { and NPs }\end{array}$} & \multirow{4}{*}{$9.0 \pm 0.1$} & \multirow{4}{*}{500} & \multirow{4}{*}{250} & - & - & 8.5 \\
\hline & & & & & $\mathrm{Al}_{2} \mathrm{O}_{3}$ & $\begin{array}{l}1.0 \mathrm{wt} \% \\
0.5 \mathrm{wt} \%\end{array}$ & $\begin{array}{l}11 \\
9\end{array}$ \\
\hline & & & & & \multirow{2}{*}{$\mathrm{SiO}_{2}$} & $1.0 \mathrm{wt} \%$ & 15 \\
\hline & & & & & & $0.5 \mathrm{wt} \%$ & 7.5 \\
\hline \multirow{4}{*}{$\begin{array}{l}\text { Mahmoud } \\
\text { et al. } \\
(2018 b)\end{array}$} & \multirow{4}{*}{$\begin{array}{c}319 \text { ml Water, } \mathrm{Ca}- \\
\text { Bentonite, Hyper- } \\
\text { branched Polymer, } \\
\text { PAC-R, } \\
\text { Lignosulfonate Thiner, } \\
\mathrm{NaOH} \mathrm{CaCO}_{3}, \\
\mathrm{Mn}_{3} \mathrm{O}_{4} \text {, and } \mathrm{NPs}\end{array}$} & \multirow{4}{*}{$9.6 \pm 0.1$} & \multirow{3}{*}{300} & \multirow{3}{*}{250} & - & - & 7.7 \\
\hline & & & & & \multirow[b]{2}{*}{$\mathrm{Fe}_{2} \mathrm{O}_{3}$} & $1 \mathrm{wt} \%$ & 8.9 \\
\hline & & & & & & $0.5 \mathrm{wt} \%$ & 7.4 \\
\hline & & & 350 & 500 & $\mathrm{Fe}_{2} \mathrm{O}_{3}$ & $0.5 \mathrm{wt} \%$ & 6.9 \\
\hline
\end{tabular}

NPs Applications as Shale Stabilizers and Wellbore Strengthening Agents

The work in [27] discussed the effectiveness of silica NPs to reduce shale permeability around the wellbore. The theory explained was that the NPs are playing a key rule of plugging the pore throats and building an internal filter cake, which reducing the invasion of the fluids into shale formations. It was noticed that the NPs plugged the pores that have the same NP size. Additionally, a group of NPs can aggregate together and plug one big pore throat. Moreover, [5] investigated the capability of nonmodified silica NPs as shale plugging additives in the drilling fluid. In this study, six different types of commercial and nonmodified silica NPs were examined and screened. A higher reduction in the used Atoka shale permeability was observed upon the addition of nonmodified NPs. The most effective sizes and concentrations of NPs to get a highly reduction in the shale permeability was reported to be from 7 to $15 \mathrm{~nm}$ and 10 wt.\%, respectively.

The work in [29] examined the use of silica NPs with a uniform diameter of $20 \mathrm{~nm}$ as wellbore strengthening agents. Tests were conducted on real shale samples to simulate the water invasion process. Water invasion into shale was found to be reduced by 10 to 100 times, where the NPs effectively plugged the pores with or without the existence of microcracks. Later in the same year, [32] examined silica NPs as a fluid loss reducer in a surfactant-polymer-based drilling fluid. They found that this type of NPs can be used instead of calcium carbonates which used as an efficient inorganic bridging agent but difficult to be maintained. Furthermore, increasing the concentration of NPs reduced the fluid loss volume but limited by the aggregation of NPs in the polymer. They concluded the effectiveness of using NPs for drilling shale as a bridging agent to maintain wellbore stability. 
The work in [33] suggested an optimum concentration below 1 wt.\% of nanosilica to improve the shale stability. The collected SEM images after performing the tests showed good plugging which means good shale inhibition. They also reported improved-rheological profiles with less effect on the fluid loss properties. A mixture of both $\mathrm{SiO}_{2}$ and GNPs was also investigated to explore the NPs' potential to enhance the inhibition of woodford shales [4]. The immersion and cutting dispersion tests showed good NPs' stability, which indicating less cutting dispersion and good inhibition even in high illitic shales.

$\mathrm{SiO}_{2}$ NPs were thoroughly examined as borehole strengthening and shale stability agents. The efficiency of $\mathrm{SiO}_{2}$ NPs-based drilling fluids, for borehole stability of shale, was found to be dependent on the type of formation, the type, size, surface charge potential, and concentration of NPs, and the interaction between NPs and shale formation under the borehole conditions[10]. Fig. 4 shows a diagram of the electrostatic interaction between charged NPs and shale.

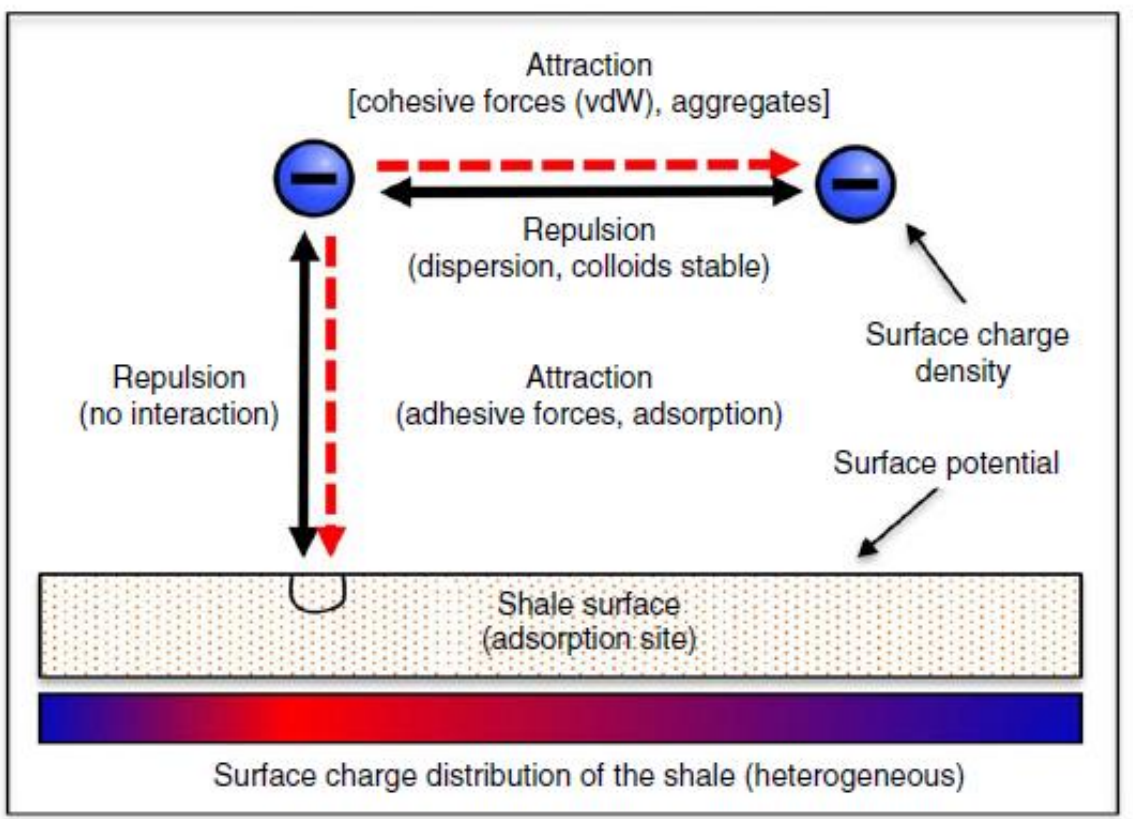

Fig. 4 The diagram shows the electrostatic interaction between charged NPs and shale (modified after [10]).

\section{3- Characterization of potential Egyptian shale formations}

\section{Materials and Method}

The black shales are widely distributed in Egypt in several horizons of different geologic ages. Two black shale samples are obtained from two different potential formations; the Duwi Formation at Safaga-Quseir area, and Dakhla Formation, which is located in the southern part of Egypt (Dakhla-Kharga Oases; Nile Valley, Red Sea District) (Fig. 5). 

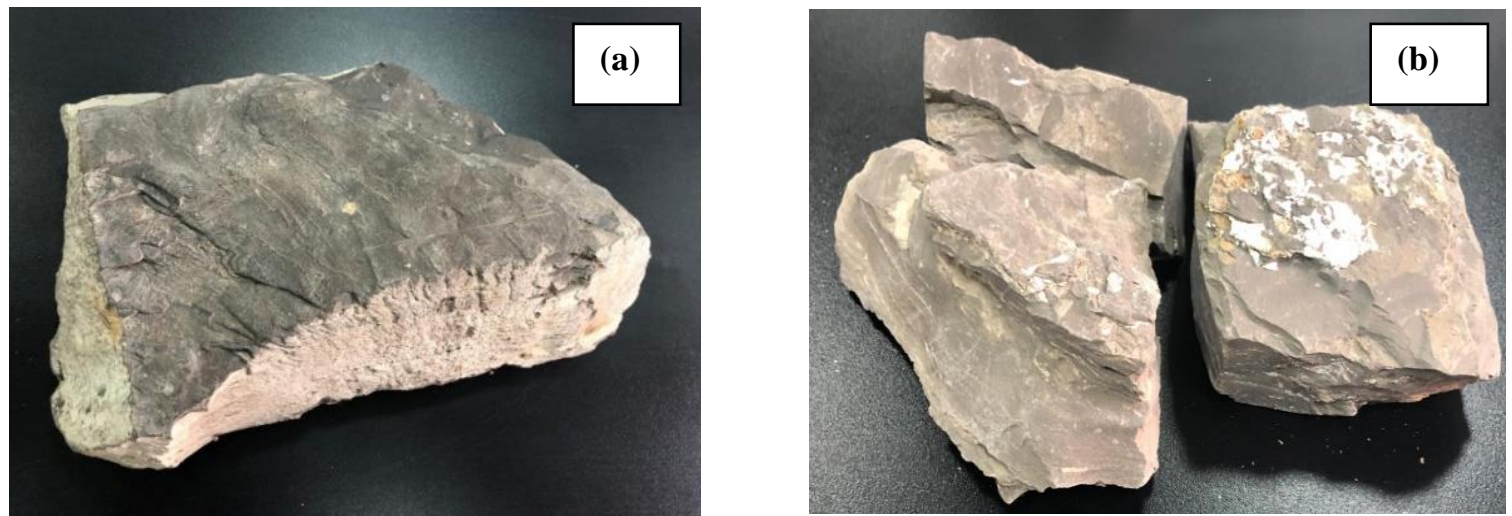

Fig. 5 Two shale samples; (a) Duwi Formation, and (b) Dakhla Formation shale.

The previous studies revealed that the Duwi Formation shale deposits, were assessed by the rock eval pyrolysis (REP), for calculating its shale oil potentiality. The studied Duwi shale is evaluated as a very good source rock with total organic carbon (TOC) of greater than $2 \mathrm{wt} . \%$ [8]. The Dakhla Formation consists of light pink weathering calcareous and gypsiferous shales and marls, grading upward to grey and brown highly fissile shale. It was deposited in a deepening near-shore marine shelf environment. The thickness of the formation is variable, ranging from less than $50 \mathrm{~m}$ near Safaga to as much as $165 \mathrm{~m}$ at Gebel Atshan [9].

Both samples are characterized for the objective of a future investigation of the effect of using NPs-based drilling fluids on their swelling properties and shale-stability. The X-ray diffraction (XRD) was used to determine the mineral composition of each sample, which showed a higher content of montomorillonite with a higher affinity to swell. Swelling of shales with the adsorption of water while drilling can cause wellbore instability and thus, shale formation collapse, which is one of the leading problems while drilling oil and gas wells [16].

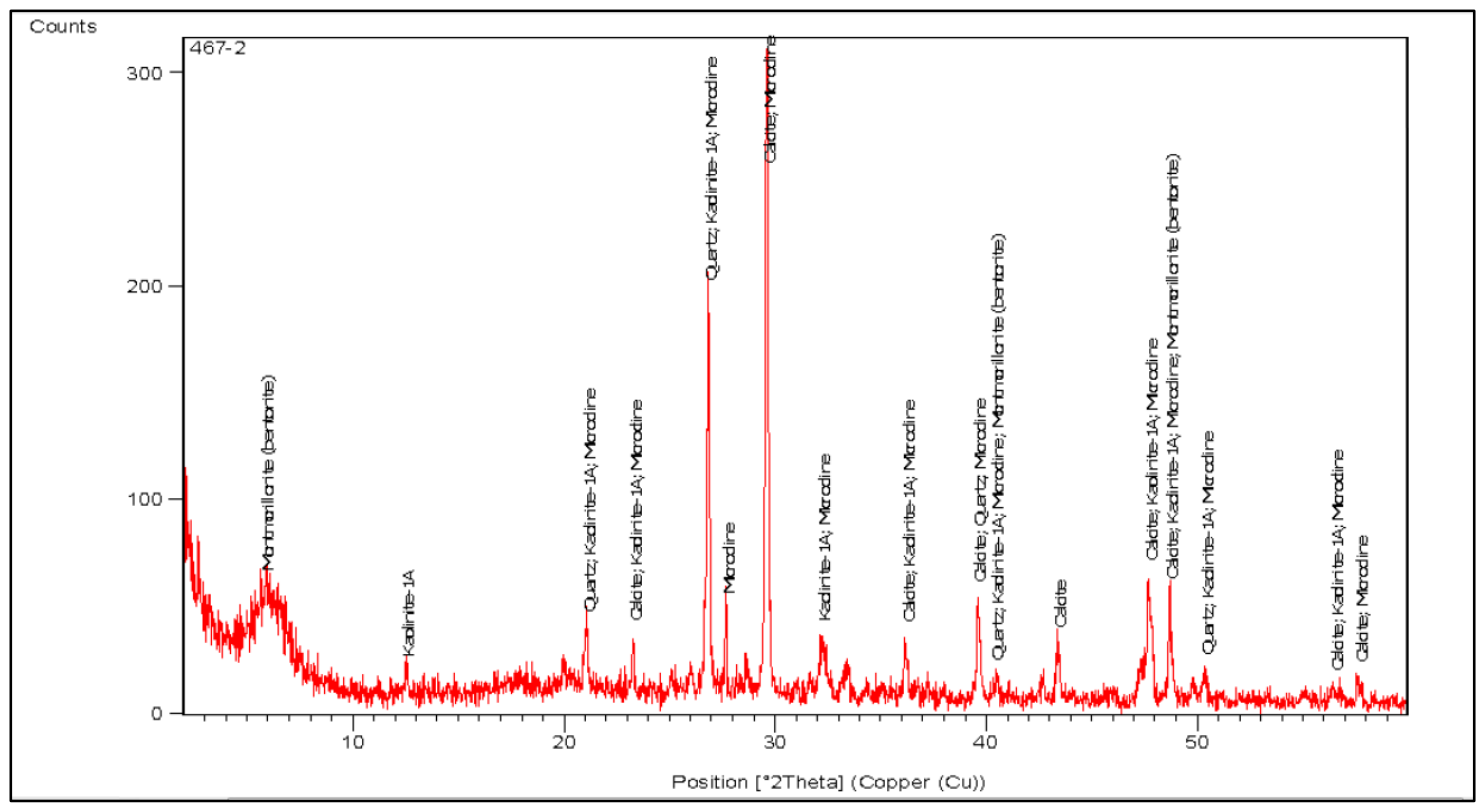

Fig. 6 XRD analysis of the Duwi Formation shale sample. 
The current research found that, the first part of the XRD analysis for the bulk Duwi shale sample showed that the bulk minerals are mainly quartz, calcite in addition to their clay minerals, which are mainly smectite and kaolinite (Fig. 6).

Where the analysis of the bulk Dakhla sample showed that it composed mainly of clay minerals with a very small quartz content (Fig. 7).

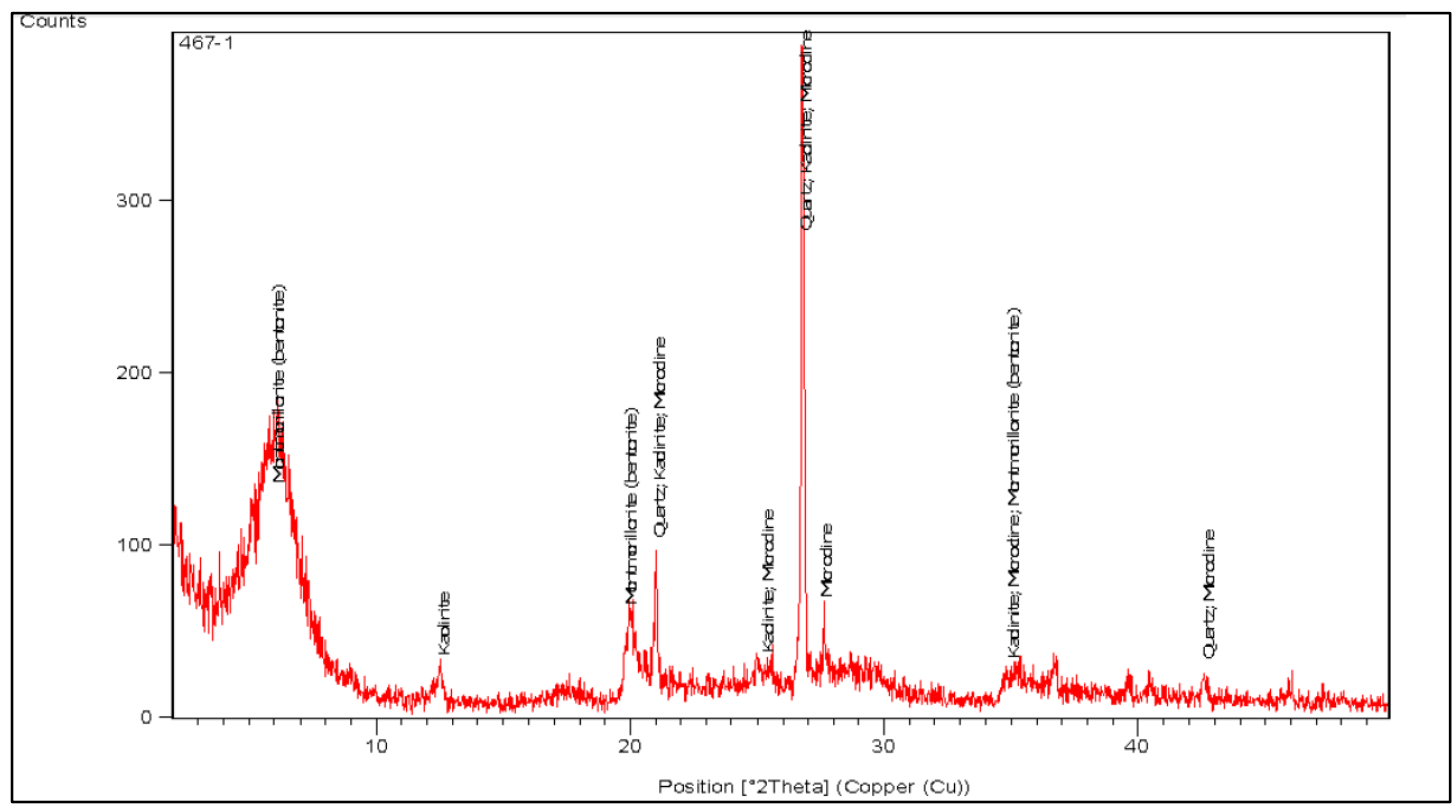

Fig. 7 XRD analysis of the Dakhla formation shale sample.

Then, the second part of the analysis for the clay size fraction was separated by the method described by [21] using dilute chemicals. The suspension was disaggregated using ultrasonic equipment, then washed until it shows turbidity (conductivity 50ms); and then centrifuged in order to separate the clay size fraction from the silt size. The thick slurry was smeared onto a glass slide with a pipette and dried under room temperature.

\section{X-Ray diffraction analysis (XRD)}

The two samples were analyzed by Ni-filtered $\mathrm{Cu}-$ Ká radiation $(50 \mathrm{kV}, 30 \mathrm{~mA})$ from an APD $1700 \mathrm{X}$-ray diffractometer. The analysis was conducted on oriented clay size fractions as well as treated mounts using ethylene glycol and heating at $550^{\circ} \mathrm{C}$ for $4 \mathrm{~h}$. After glycolation and heating of the selected samples for the Duwi and Dakhla shale, respectively, to obtain the exact identification of the clay minerals in each sample (Fig.s 8 and 9). 


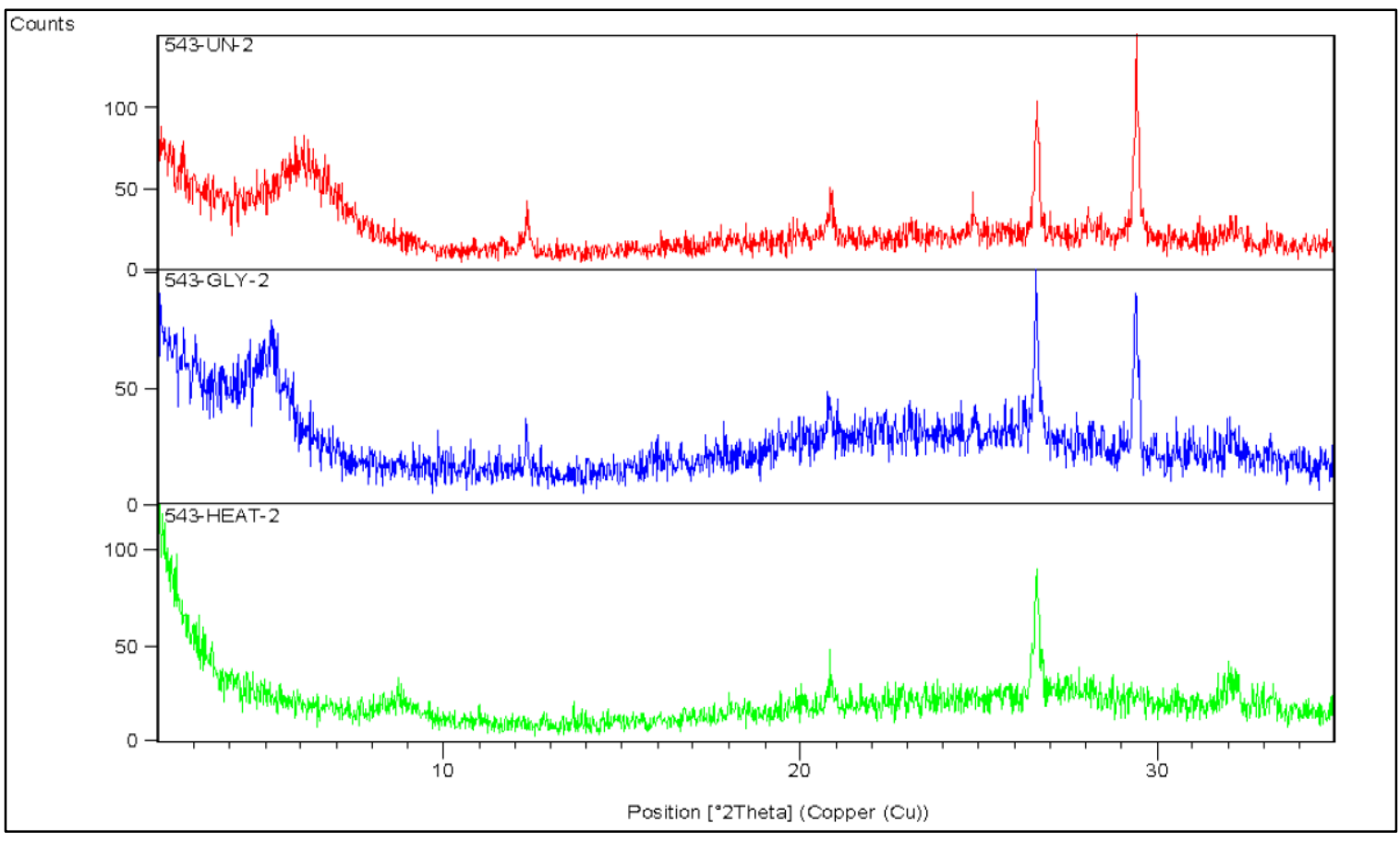

Fig.8 XRD analysis of the oriented, glycolated and heated phases of the Duwi formation shale sample.

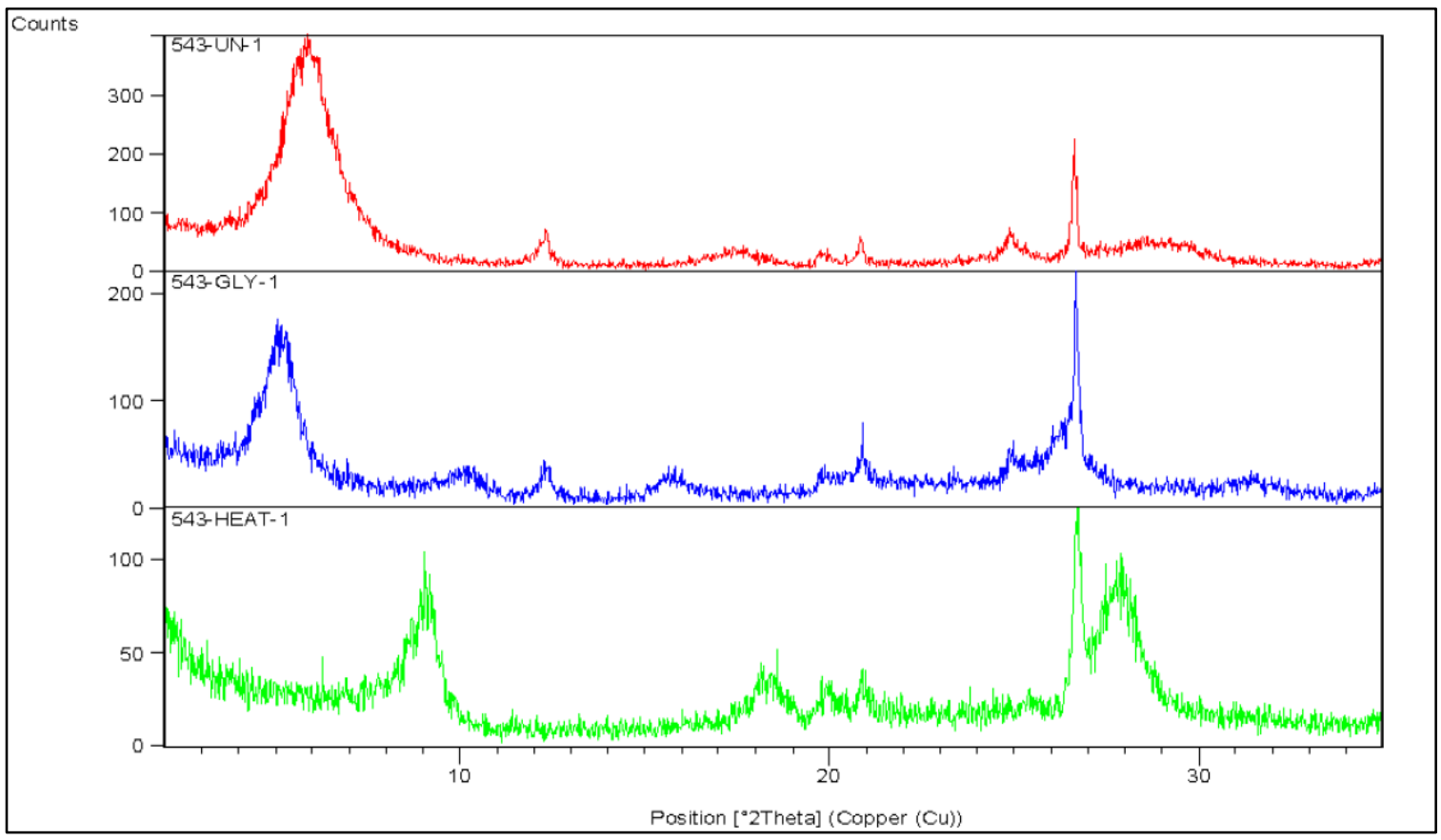

Fig. 9 XRD analysis of the oriented, glycolated, and heated phases of the Dakhla formation shale sample.

Table 2 shows the identified clay content in Duwi and Dakhla shale samples after following the [21]. The results showed that, Dakhla shale has Na-montmorillonite content of $80 \%$, which indicates higher swellability. In the meanwhile, the Duwi shale was found to have lower montmorillonite content and higher calcite ratio. 
Table 2: Results of XRD analysis and identification of clay content in Duwi and Dakhla formation shale samples.

\begin{tabular}{|c|c|c|c|}
\hline Shale Sample & Mineral Name & Chemical Formula & $\begin{array}{c}\text { SemiQuant } \\
{[\%]}\end{array}$ \\
\hline \multirow{3}{*}{ Duwi Formation } & Kaolinite-2M & $\mathrm{Al}_{2} \mathrm{Si}_{2} \mathrm{O}_{5}(\mathrm{O} \mathrm{H})_{4}$ & 7 \\
\hline & $\begin{array}{r}\text { Montmorillonite, } \\
\text { syn }\end{array}$ & $\mathrm{Al}_{2} \mathrm{O}_{3} \cdot 4 \mathrm{Si} \mathrm{O}_{2} \cdot \mathrm{x} \mathrm{H}_{2} \mathrm{O}$ & 32 \\
\hline & Illite & $\begin{array}{r}2 \mathrm{~K}_{2} \mathrm{O} \cdot 3 \mathrm{Mg} \mathrm{O} \cdot \mathrm{Al}_{2} \mathrm{O}_{3} \cdot 24 \mathrm{Si} \mathrm{O}_{2} \cdot 12 \\
\mathrm{H}_{2} \mathrm{O}\end{array}$ & 6 \\
\hline \multirow{3}{*}{ Dakhla Formation } & Kaolinite & $\mathrm{Al}_{2} \mathrm{Si}_{2} \mathrm{O}_{5}(\mathrm{O} \mathrm{H})_{4}$ & 19 \\
\hline & $\begin{array}{r}\text { Montmorillonite- } \\
14 \mathrm{~A}\end{array}$ & $\mathrm{Na}_{0.3}(\mathrm{Al}, \mathrm{Mg})_{2} \mathrm{Si}_{4} \mathrm{O}_{10}(\mathrm{OH})_{2} \cdot \mathrm{x} \mathrm{H}_{2} \mathrm{O}$ & 80 \\
\hline & Illite-2M2 & $\mathrm{K}_{0.7} \mathrm{Al}_{2.1}(\mathrm{Si}, \mathrm{Al})_{4} \mathrm{O}_{10}(\mathrm{O} \mathrm{H})_{2}$ & 1 \\
\hline
\end{tabular}

The effect of using different NPs-types, -sizes, and -concentrations, while preparing muds to drill Duwi and Dakhla shale formations, on the shale swellability will be investigated. Additionally, the properties of the NPs-based drilling fluids will be tested thoroughly in order to obtain the optimum formulation, which can mitigate the swelling and collapse of shale formations and thus, results in successful drilling operations. The results out of those studies will be reported thoroughly in future publications.

The potential efficiency of NPs can be accredited to their small sizes and thus, high surfacearea-to-volume ratio. As aforementioned, NPs were showed promising enhancements on the rheological and filtrate invasion properties of the drilling fluids. Moreover, swelling and collapse of shale formations is expected under drilling with water-based mud, which might result in complicating the drilling operation. Adding NPs to the drilling mud was found to minimize the shale permeability by plugging Nano-pores and thus, promote the wellbore stability.

\section{4- Conclusions and recommendations}

Based on a review of the previous literature and from the XRD analysis regarding to the effect of NPs on the properties of drilling fluids. The following conclusions and recommendations can be drawn:

1. The Herschel-Bulkley was found to be the best representing model for the rheological behavior of most of the investigated NPs-based drilling fluids.

2. NPs-concentrations of less than $1.0 \mathrm{wt}$.\% are recommended for generating a goodquality filter cake and better rheological performance. The best cake characteristics were obtained at NPs-concentrations of less 0.3-0.5 wt.\%. However, using higher NPs-concentrations can result in the agglomeration of NPs, which reduced the filter cake efficiency (i. e., producing a thick, permeable filter cake with high fluid loss).

3. Metal oxide NPs are the most promising types in the field of drilling fluids industry. The higher NPs-stability in suspensions, suitable surface charge, in addition to the size of NPs are the most dominatnt parameters in proper functionality. 
4. NPs, especially nanosilica, can effectively plug the shale formations and perform as a bridging material when mixing with water-based drilling fluids in suitable concentrations, which can provide better wellbore stability and a potential solution for environmentally-sensitive areas where the oil-based mud is commonly used.

Two Egyptian-shale samples were collected and analyzed on the basis of their clay minerals. The XRD analysis of the Duwi-shale sample showed higher content of quartz and calcite with almost $32 \%$ of montmorillonite. In the meanwhile, the XRD analysis of the Dakhla-shale sample showed higher content of Na-montmorillonite of about $80 \%$. The higher montmorillonite content in shales causes swelling with the adsorption of water while drilling. Swelling of shale formations while drilling can cause wellbore instability and collapse of the formation, which is one of the leading problems while drilling oil and gas wells.

\section{Acknowledgements}

The authors would like to express appreciation for the support of the Future University in Egypt (FUE). The first author would like also to extended his appreciation for the faculty members in the department of petroleum engineering, Cairo University, for their continuous encouragement and support.

\section{References}

[1] J. Abdo, and M. D. Haneef, "Nano-Enhanced Drilling Fluids: Pioneering Approach to Overcome Uncompromising Drilling Problems". J. Energy Resour. Technol, Vol. 134 (1): 014501, 2012. http://doi:10.1115/1.4005244.

[2] M. T. Al-saba, A. Al Fadhli, A. Marafi et al., "Application of Nanoparticles in Improving Rheological Properties of Water Based Drilling Fluids. Presented at the SPE Kingdom of Saudi Arabia Annual Technical Symposium and Exhibition, Dammam, Saudi Arabia, 23-26 April 2018. SPE-192239-MS. http://dx.doi.org/10.2118/192239-MS.

[3] Md. Amanullah, K. Al-Arfaj, and Z. Al-Abdullatif, "Preliminary Test Results of Nano-Based Drilling Fluids for Oil and Gas Field Application". Presented at the SPE/IADC Conference and Exhibition, Amsterdam, The Netherlands, 1-3 March 2011. SPE/IADC 139534. http://dx.doi.org/10.2118/139534-MS.

[4] J. Aramendiz, A. H. Imqam, and S. M. Fakher, "Design and Evaluation of a Water-Based Drilling Fluid Formulation Using $\mathrm{SiO}$ and Graphene Oxide Nanoparticles for Unconventional Shales". International Petroleum Technology Conference Beijing, China, 26-28 March 2019. IPTC-19342-MS. https://doi.org/10.2523/IPTC-19342-MS.

[5] J. Cai, M. E. Chenevert, M. M. Sharma,et al., "Decreasing Water Invasion into Atoka Shale Using Nanomodified Silica Nanoparticles”. SPE Drill \& Compl, Vol. 27 (1), pp. 103-112, , 2012. SPE-146979PA. http://dx.doi.org/10.2118/146979-PA.

[6] O. Contreras, G. Hareland, M. Husein et al. , "Application of In-House Prepared Nanoparticles as Filtration Control Additive to Reduce Formation Damage. Presented at the International Symposium and Exhibition on Formation Damage Control", Lafayette, Louisiana, 26-28 February 2014. SPE-168116-MS. http://dx.doi.org/10.2118/168116-MS.

[7] M. Fereydouni, S. Sabbaghi, R. Saboori et al., "Effect of Polyanionic Cellulose Polymer Nanoparticles on Rheological Properties of Drilling Mud”. Int. J. Nanosci. Nanotechnol. Vol. 8 (3) pp. 171-174, 2012. http://ijnnonline.net/article_3902_44daeb1450e7d68c149fe717bd1b8dc4.pdf.

[8] M. F. Ghanem, M. A. El-Fakharany, M. G. Temraz et al, "Upper Cretaceous Duwi Formation Shale's Oil Potentiality Safaga-Quseir, Red Sea, Egypt”. Egypt J. Pet, Vol. 27 (4), pp. 1313-1323, 2018. https://doi:10.1016/j.ejpe.2018.08.004

[9] D. C. Greene, "Structural Geology of The Quseir Area, Red Sea Coast, Egypt". Contribution No. 12, Department of Geology and Geography, University of Massachusetts, Amherst, Massachusetts, 1984. http://www.geo.umass.edu/research/Geosciences\%20Publications/v52GreeneCoveredlf.pdf.

[10] B. B. Hoxha, E. van Oort, and H. Daigle, "How Do Nanoparticles Stabilize Shale? SPE Drill \& Compl" 34 (2): 1-16. SPE-184574-PA, 2019. https://doi.org/10.2118/184574-PA. 
[11] A. R. Ismail, A. Aftab, Z. H. Ibupoto et al., "The Novel Approach for the Enhancement of Rheological Properties of Water-Based Drilling Fluids by Using Multi-Walled Carbon Nanotube, Nanosilica and Glass Beads”. J. Petrol. Sci. Eng Vol. 139, pp. 264-275, 2016. https://doi.org/10.1016/j.petrol.2016.01.036.

[12] S. M. Javeri, Z. W. Haindade, and C. B. Jere, "Mitigation Loss Circulation and Differential Sticking Problems Using Silicon Nanoparticles". Presented at the SPE/IADC Middle East Drilling Technology Conference and Exhibition, Muscat, Oman, 24-26 October 2011. SPE-145840-M. http://dx.doi.org/10.2118/145840-MS.

[13] Y. Jung, M. Barry, J. -K. Lee, et al., "Effect of Nanoparticle-Additives on the Rheological Properties of ClayBased Fluids at High Temperature and High Pressure". Presented at the AADE National Technical Conference and Exhibition, Houston, Texas, 12-14 April 2011. AADE-11-NTCE-2.

[14] D. V. Kosynkin, G. Ceriotti, K. C. Wilson et al., "Graphene Oxide as a High-Performance Fluid-Loss-Control Additive in Water-Based Drilling Fluids”. ACS Appl. Mater. Interfaces Vol. 4 (1), pp. 222-227, 2012. http://pubs.acs.org/doi/abs/10.1021/am2012799.

[15] M. -C. Li,, Q. Wu, K. Song et al., "Cellulose Nanocrystals and Polyanionic Cellulose as Additives in Bentonite Water-Based Drilling Fluids: Rheological Modeling and Filtration Mechanisms”. Ind. Eng. Chem. Res. Vol. 55 (1) pp.133-143, 2015. https://doi:10.1021/acs.iecr.5b03510.

[16] Q. Lyu, P. G. Ranjith, X. et al. Long, “A Review of Shale Swelling by Water Adsorption. J. Nat. Gas”. Sc. Eng. Vol. 27 (3) pp. 1421-1431, 2015. https://doi.org/10.1016/j.jngse.2015.10.004Get rights and content.

[17] A. Mady, O. Mahmoud, and A. Dahab, "Can Nanoparticles Improve the Characteristics of Drilling Fluids?”. Presented at the 13th International Conference on Mining, Metallurgical, and Petroleum Engineering, Suez, Egypt, 25-27 October 2019..

[18] O. Mahmoud, and H. A. Nasr-El-Din, "Formation Damage Assessment and Filter Cake Characterization of NPs/Ca-Bentonite Fluids for Drilling Harsh Environments Using Computed-Tomography Scan". Presented at the SPE Trinidad and Tobago Section Energy Resources Conference, Port of Spain, Trinidad $\begin{array}{lllll}\text { and } \quad \text { Tobago, } & 25-27 & \text { June } & \text { SPE-191155-MS. }\end{array}$ https://doi.org/10.2118/191155-MS.

[19] O. Mahmoud, H. A. Nasr-El-Din, Z. Vryzas et al., "Using Ferric Oxide and Silica Nanoparticles to Develop Modified Calcium Bentonite Drilling Fluids". SPE Drill \& Compl, Vol. 33 (1), pp. 12-26. SPE-178949-PA, 2018. https://doi.org/10.2118/178949-PA.

[20] O. Mahmoud, H. A. Nasr-El-Din, Z. Vryzas et al., "Effect of Ferric Oxide Nanoparticles on the Properties of Filter Cake Formed by Calcium Bentonite-Based Drilling Muds”. SPE Drill \& Compl, Vol. 33 (4), pp.12-26. SPE-178949-PA, 2018. https://doi.org/10.2118/184572-PA.

[21] D.M. Moore and R.C. Jr Reynolds, "X-Ray Diffraction and the Identification Analysis of Clay Minerals. Oxford: Oxford University Press. 332 pp, 1997.

[22] A. Parizad and K. Shahbazi, "Experimental Investigation of the Effects of SnO2 Nanoparticles and $\mathrm{KCl}$ salt on a Water Base Drilling Fluid Properties". Can. J. Chem. Eng. Vol. 94 (10), pp. 1924-1938, 2016. http://doi: 10.1002/cjce.22575.

[23] S. Ponmani, R. Nagarajan, and J. S. Sangwai, "Effect of Nanofluids of $\mathrm{CuO}$ and $\mathrm{ZnO}$ in Polyethylene Glycol and Polyvinylpyrrolidone on the Thermal, Electrical, and Filtration-loss Properties of Water-Based Drilling Fluids". SPE J. Vol. 21 (2), pp. 405-415. 2016. https://doi.org/10.2118/178919-PA.

[24] R. Saboori, S. Sabbaghi, D. Mowla et al., "Decreasing of Water Loss and Mud Cake Thickness by CMC Nanoparticles in Mud Drilling”. Int. J. Nano Dimens. Vol. 3 (2), pp.101-104, 2012. DOI: $10.7508 /$ IJND.2012.02.002.

[25] A. H. Salih and H. Bilgesu, "Investigation of Rheological and Filtration Properties of Water-Based Drilling Fluids Using Various Anionic Nanoparticles. Presented at the SPE Western Regional Meeting”, Bakersfield, California, USA, 23-27 April 2017. SPE-185638-MS. https://doi.org/10.2118/185638-MS.

[26] A. H. Salih, T. A. Elshehabi, H. I. Bilgesu, «Impact of Nanomaterials on the Rheological and Filtration Properties of Water-Based Drilling Fluids". Presented at the SPE Eastern Regional Meeting, Canton, Ohio, USA, 13-15 September 2016. SPE-184067-MS. https://doi.org/10.2118/184067-MS.

[27] R. Sandera, "Global Natural Gas Reserves - A Heuristic Viewpoint (part 1 of 2): Middle East Economic Survey", 49 (11), 13 March 2006. http://archives.mees.com/issues/298/articles/12167.

[28] T. Sensoy, M. E. Chenevert and M. M. Sharma, "Minimizing Water Invasion in Shale Using Nanoparticles". Presented at the SPE Annual Technical Conference and Exhibition, New Orleans, Louisiana, USA, 4-7 October 2009. SPE-124429-MS. https://doi.org/10.2118/124429-MS.

[29] M. M. Sharma, R. Zhang, M. E. Chenevert et al., "A New Family of Nanoparticle Based Drilling Fluids. Presented at the SPE Annual Technical Conference and Exhibition", San Antonio, Texas, 8-10 October 2012. SPE-160045-MS. https://doi.org/10.2118/160045-MS. 
[30] S. R. Smith, R. Rafati, A. S. Haddad et al., "Application of Aluminum Oxide Nanoparticles to Enhance Rheological and Filtration Properties of Water Based Muds at HPHT Conditions". Colloids and Surfaces A Vol. 537, pp. 361-371, 2018. https://doi.org/10.1016/j.colsurfa.2017.10.050.

[31] K. Song, Q. Wu, M. Li et al., "Water-Based Bentonite Drilling Fluids Modified by Novel Biopolymer for Minimizing Fluid Loss and Formation Damage”. Colloids and Surfaces A: Physicochem. Eng. Aspects, Vol. 507, pp. 58-66, 2016. https://doi.org/10.1016/j.colsurfa.2016.07.092.

[32] J. T. Srivatsa and, M. B. Ziaja, "An Experimental Investigation on Use of Nanoparticles as Fluid Loss Additives in a Surfactant-Polymer Based Drilling Fluid". Presented at the International Technology Conference, Bangkok, Thailand, 7-9 February 2011. IPTC-14952-MS. https://doi.org/10.2523/IPTC-14952MS.

[33] S. Taraghikhah, M. K. Mohammadi, and K. T. Nowtaraki, "Multifunctional Nanoadditive in Water Based Drilling Fluid for Improving Shale Stability". Presented at the International Petroleum Technology Conference, Doha, Qatar, 6-9 December 2015. IPTC-18323-MS. https://doi.org/10.2523/IPTC-18323-MS. 